\title{
Rapid Analysis of Adulterated Dexamethasone in Joint-Pain Killer Traditional Herbal Medicine (THM) Using Infrared Spectroscopy
}

\author{
Ardi Nugroho*, Fany Devita Ritonga \\ Pharmacy Department, Universitas Islam Indonesia, Yogyakarta, 55582, \\ 085192982951 \\ *ardi.nugroho@uii.ac.id
}

\begin{abstract}
A rapid, non-destructive and reagent-free infrared spectroscopy combined with Partial Least Square (PLS) has been developed for the dexamethasone quantification in jointpain killer traditional herbal medicine (THM). The main aim of this study is to select the best wavenumbers that are capable of providing the high coefficient of determination (R2), low values of Root Mean Square Error of Calibration (RMSEC), Root Mean Square Error of Cross Validation (RMSECV) and predictive residual error sum of squares (PRESS). Finally, wavenumbers 3646, 3642, 2461, 2453, 2432, 2406, 2229, 2209, 2197, 2097, 2092, 2064, 2059, 2047, 2026, 2009, 1969, and $1513 \mathrm{~cm}^{-1}$ were selected for the prediction of dexamethasone in the joint-pain killer traditional herbal medicine. The correlation between the actual values of dexamethasone determined in joint-pain killer traditional herbal medicine using infrared spectroscopy combined with $P L S$ revealed the $R 2$ values of 0.9988. The RMSEC values obtained 0,009455. The PRESS and RMSECV value obtained as the results of cross-validation model selection for dexamethasone in joint-pain killer traditional herbal medicine were 0,0022721.00 and 0,02902, respectively. The high value of $R 2$ and low value of RMSEC, RMSECV and PRESS indicated that this method had high accuracy and precision in a validated condition for the dexamethasone quantification in the joint-pain killer traditional herbal medicine. These results indicated that infrared spectroscopy combined with PLS can be an alternative method for the dexamethasone determination in joint-pain killer traditional herbal medicine
\end{abstract}

Keywords: Dexamethasone; Infrared Spectroscopy; Partial Least Square.

\begin{abstract}
Abstrak
Kombinasi antara Spektroskopi inframerah yang cepat, tidak merusak dan bebas reagen dengan Partial Least Square (PLS) telah dikembangkan untuk kuantifikasi deksametason pada jamu pereda nyeri sendi. Tujuan utama dari penelitian ini adalah untuk memilih bilangan gelombang terbaik yang mampu memberikan koefisien determinasi tinggi $\left(\mathrm{R}^{2}\right.$ ), nilai Root Mean Square Error of Calibration (RMSEC), Root Mean Square Error of Cross Validation (RMSECV) dan Predictive Residual Error Sum Of Squares (PRESS) yang rendah. Akhirnya, bilangan gelombang 3646, 3642, 2461, 2453, 2432, 2406, 2229, 2209, 2197, 2097, 2092, 2064, 2059, 2047, 2026, 2009, 1969, dan $1513 \mathrm{~cm}^{-1}$ dipilih untuk memprediksi deksametason pada jamu pereda nyeri sendi. Korelasi antara nilai-nilai aktual deksametasone yang ditentukan dalam jamu pereda nyeri sendi menggunakan spektroskopi inframerah dikombinasikan dengan PLS menghasilkan nilai $\mathrm{R}^{2}$ 0,9988. Nilai RMSEC diperoleh 0,009455, Nilai PRESS dan RMSECV yang diperoleh dari hasil seleksi validasi silang untuk deksametason pada
\end{abstract}


jamu pereda nyeri sendi masing-masing 0,0022721 dan 0,02902. Nilai $R^{2}$ yang tinggi dan nilai RMSEC, RMSECV, dan PRESS yang rendah menunjukkan bahwa metode ini memiliki akurasi dan presisi yang tinggi dalam kondisi yang tervalidasi untuk kuantifikasi deksamethasone pada jamu. Hasil ini menunjukkan bahwa spektroskopi inframerah yang dikombinasikan dengan PLS dapat menjadi metode alternatif untuk penentuan kadar deksametason pada jamu pereda nyeri sendi.

Kata Kunci: deksametason; spektroskopi inframerah; Partial Least Square

\section{Introduction}

Infrared spectroscopy is the simplest and green analytical methods. It is rapid and non-destructive analysis without any previous sample pretreatment. Moreover, when no sample pretreatment is required, there is reagent-free during the analytical step. Thus, potentially harmful reagents are avoided and clearly benefits for the environment and cost-effective of chemical waste. Additionally, infrared spectroscopy could be used to analyze any samples (solids, liquids or gases) at any levels (macroscopic and microscopic) (Moros et al., 2010). Infrared spectroscopy, hence, is a very powerful alternative for a common analytical method especially in determining an adulterated drug in traditional herbal medicine.

One of common adulterated drugs in traditional herbal medicine is dexamethasone. This drug however can cause many side effects such as diabetes mellitus, hypertension, obesity, osteoporosis, infections diabetes, hypertension, lipids, oedema, osteoporosis, infections, osteonecrosis, myopathy, eye problems, skin problems, neuropsychological effects and many other side effects (Curtis et al., 2006; Hoes et al., 2009; Poetker and Reh, 2010; W. J. Bijlsma and Buttgereit, 2016). For a long time use, the risk from these side effects will increase.

The adulterated dexamethasone in traditional herbal medicine is commonly determined using chromathograpic methods. Until now, several authors have reported the methods for the determination of adulterated dexamethasone in traditional herbal medicine, including UHPLC-Q-Orbitrap HRMS (Zhou et al., 2016), HPLC (Jin et al., 2018; Zhang et al., 2011), and LC-MS/MS (Cho et al., 2014). However, these chromatographic methods are destructive, time-wasting, very highpriced and containing many toxic reagents (Mukherjee and Houghton, 2009; Sanzini et al., 2011). Therefore, 
infrared spectroscopy is an excelent candidate as an alternative analytical method.

Infrared spectroscopy with chemometrics, has been widely used in the determination of adulterant in traditional herbal medicine (Cebi et al., 2017; Rohman and Che Man, 2012; Rooney et al., 2015). This is because it contains a number of biochemical fingerprints providing information about molecular structure and composition (Rohman et al., 2015). A sample of adulterated traditional herbal medicine with dexamethasone is a mixture of the authentic traditional herbal medicine and dexamethasone. The partial least square (PLS) method can be used to separate spectra of dexamethasone from the spectra of authentic traditional herbal medicine. PLS analysis of the infrared spectra of the dexamethasone in traditional herbal medicine can indicate the possibility of adulteration and no matter how few they are, the adulterated dexamethasone can be found when the number of dexamethasone is quite large. From literature review, there is no report regarding the use of infrared spectroscopy combined with partial least square for the quantification of dexamethasone in various joint-pain killer traditional herbal medicines, therefore, this study aimed to evaluate the application of infrared spectroscopy combined with partial least square in quantitative analysis of dexamethasone in various joint-pain killer traditional herbal medicine.

\section{Materials and Methods}

\section{Materials}

Six different traditional herbal medicines for joint-pain killer, were purchased from local pharmacies in Central Java and Special Region of Yogyakarta. Their names, ingredients, manufacturing details are tabulated (Table 1). Dexamethasone standard was purchased from Indonesian National Agency of Drug and Food Control. KBr used for infrared spectroscopy sampling preparation was purchased from Sigma (Aldrich, St. Louis, USA).

\section{Infrared spectral analysis}

Six joint-pain killer traditional herbal medicines purchased from local pharmacies in Yogyakarta (previously sent to our laboratory for screening on illegal dexamethasone and found negative) were used as matrices to prepare an adulterated traditional herbal medicine to serve as "self-made" samples. All samples were adulterated with dexamethasone at different levels. In this study, one sample was prepared 
for one concentration and four samples were prepared for 2 concentrations. Thus, a total of 9 samples were prepared with various concentrations from $5 \%$ to $80 \%$ (Table 2). This was done because many samples used in this study contained more than one ingredient producing very complex matrices with many compounds. Each sample was mixed with dexamethasone thoroughly using a ceramic laboratory spatula for 15 minutes to achieve the homogenous mixtures of adulterated samples. Then, the adulterated samples were stored into the air-tight and dark bottles to prevent any humid air and oxidation. The infrared spectra of were scanned using an infrared spectrophotometer Spectrum-Two (Perkin-Elmer, Ohio, US), equipped with deuterated triglycine sulphate (DTGS) detector and Dynascan $^{\mathrm{TM}}$ interferometer. Using Spectrum 10 infrared software (PerkinElmer, Ohio, US) included in the instrument, infrared spectra were scanned in the mid-infrared region of $4000-400 \mathrm{~cm}^{-1}$ with the resolution of 1 $\mathrm{cm}^{-1}$ and number of scanning of 32 . The samples were placed in a good contact with HATR accessory. These spectra were recorded as the absorbance values at each data point.

\section{Statistical analysis}

The multivariate calibration of PLS for the correlation between actual value of adulterated dexamethasone and infrared predicted value was performed using Minitab 17. The leave-one-out cross-validation procedure was used to verify the calibration model. The values of Root Mean Square Error of Calibration (RMSEC), Root Mean Square Error of Cross Validation (RMSECV), the coefficient of determination (R2) and Predictive Residual Error Sum of Squares (PRESS) were used as the validity criteria for calibration model. The linear equation from PLS calibration model was further used to calculate dexamethasone in samples.

\section{Discussion}

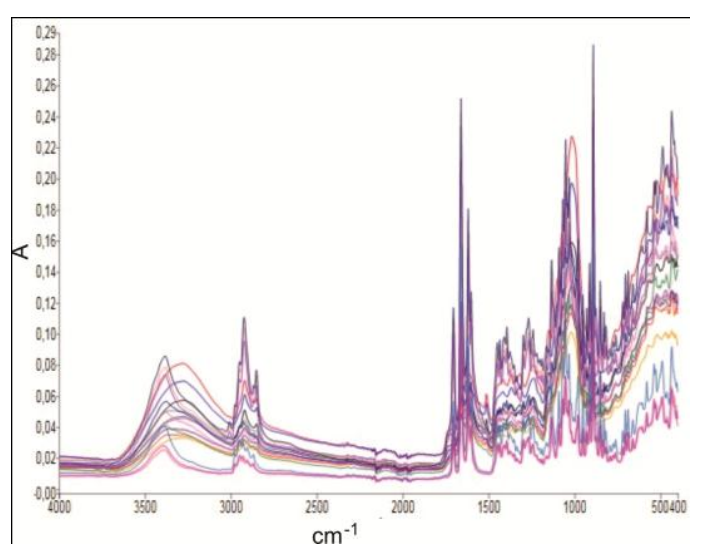

Figure 1. The FTIR Spectra from 8 Unadulterated samples. 


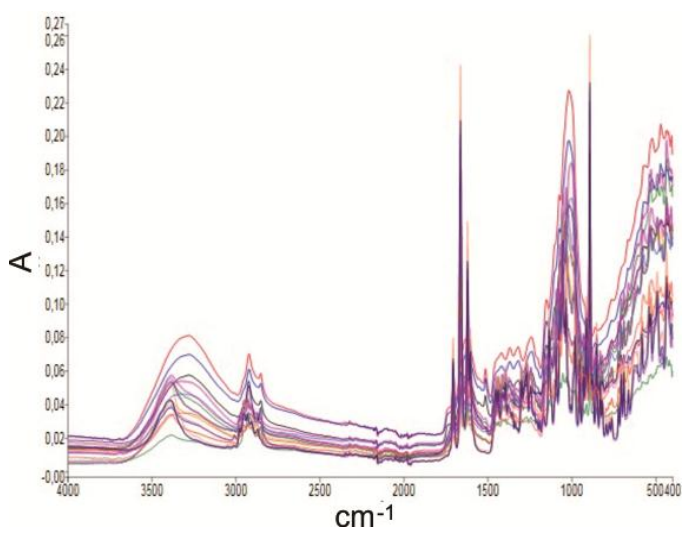

Figure 2. The FTIR Spectra from 8 samples Adulterated with dexamethasone in different concentrations.

Figure 1 and Figure 2 reveal the infrared spectra of various joint-pain killer traditional herbal medicines before and after adulterated with dexamethasone. In Figure 1 infrared spectra of all joint-pain killer traditional herbal medicine clearly showed some different peaks in certain area due to the different herbals combination that causedsome different chemical components contained. However, after the adulteration of dexamethasone in various joint-ain killer traditional herbal medicine, there were no different infrared spectra. These complex spectra were the main problems from infrared spectroscopy-the overlapping of absorption signals of various substances has made it usually difficult to interpret the spectra of adulterated samples (Chen et al., 2016). Only after using detail scrutiny, there was a bit different in terms of peak intensity (absorbance) caused by the addition of dexamethasone. This tiny bit different was clearly inadequate to determine dexamethasone content in adulterated samples. That was why the chemometrics method (PLS) was used to exploit all benefits from these complex spectra (Moros et al., 2010). Using PLS method, maximum chemical information could be obtained from spectral data by permitting the selection of wavenumbers in complex spectra and linking changes in spectra to change at some component levels simultaneously by calculating the contribution of other spectra that can interfere the spectrum (Rohman and Man, 2010). The use of infrared spectra at selected regions could increase the accuracy of analytical results (Vazquez et al., 2000). The selection of wave numbers region was based on its capability to provide the high coefficient of determination (R2) and low value of RMSEC, RMSECV and PRESS (Brereton, 2000; Rohman, 2013). After the optimization step, finally, the wave numbers of 3646 , 3642, 2461, 2453, 2432, 2406, 2229, 2209, 2197, 2097, 2092, 2064, 2059, 2047, 2026, 2009, 1969, and $1513 \mathrm{~cm}^{-1}$ were selected for the prediction of dexamethasone. The R2 value obtained from these wave numbers was 0.9988 . 
The RMSEC values obtained 0,009455. The high R2 and low RMSEC value means the calibration model from selected wavenumbers produced linear regression between predicted and calculated values from adulterated dexamethasone. Correlation between actual and predicted value from PLS is shown in Figure 3. It means that these selected wavenumbers represent the amount of dexamethasone in traditional herbal medicine. Once good model calibration was obtained, then the calibration model was validated with the cross-validation techniques leaveone-out technique. Leave-one-out is the internal validation by issuing of one data from the calibration set, and then from the remaining data created an equation and used to calculate the predicted levels of data released earlier. Alternately so that all samples of the calibration set ware issued once and treated as a sample prediction. This validation was done because one of the disadvantages of multivariate calibration was the over-fitting in which the model looks perfect with high correlation and small error, but unable to give some good results on different data. This over-fitting occurs because the number of factors far outweighs the observed numbers (Faber and Rajk,
2007). The PRESS and RMSECV value obtained as the results of crossvalidation model selection for dexamethasone in joint-pain killer traditional herbal medicine were 0,0022721 and 0,02902, respectively. Leave-one-out result from the modelling could be seen in Figure 4 . This high value of R2 and low value of RMSEC, RMSECV and PRESS indicated the high accuracy and precision of analytical method in validated condition.

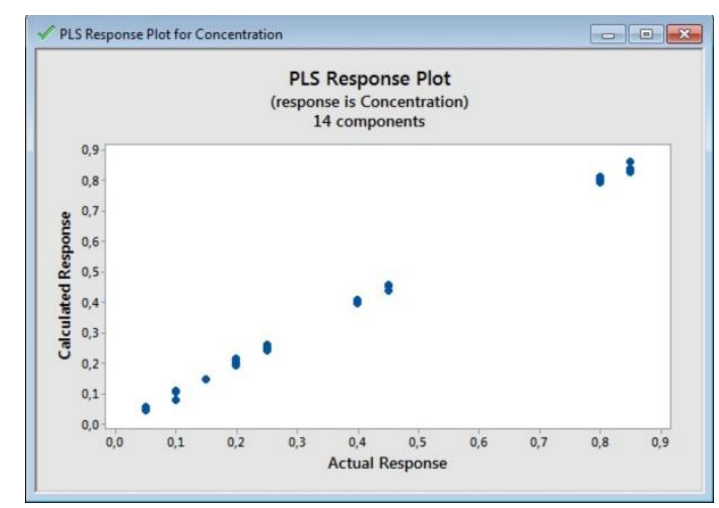

Figure 3. The PLS modelling results.

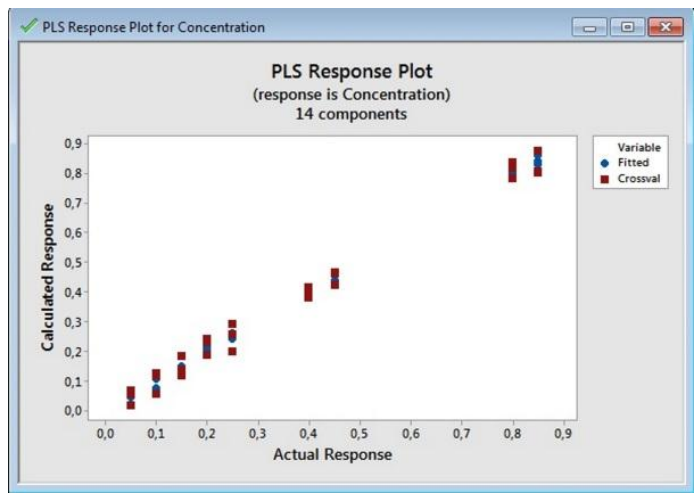

Figure 4. The PLS modelling results with leave-one-out validation technique. 
Table 1. List of six brands of marketed herbal afrodisiacs used as the adulterated sample and with their names and ingredients.

\begin{tabular}{|c|c|c|}
\hline No & $\begin{array}{l}\text { Sample } \\
\text { Name }\end{array}$ & Ingredients \\
\hline 1 & $\begin{array}{c}\text { Pegal } \\
\text { linu }\end{array}$ & 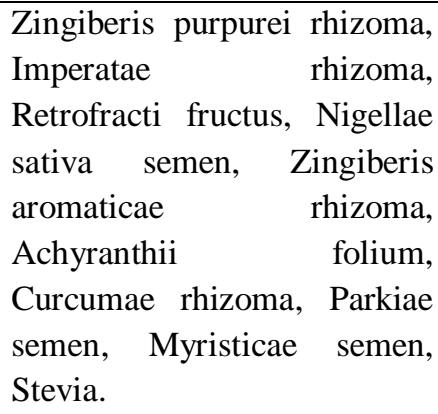 \\
\hline 2 & Wantong & $\begin{array}{l}\text { Zingiberis rhizoma, Chobati } \\
\text { rhizoma, Asari herba, } \\
\text { Epimedii herba. }\end{array}$ \\
\hline 3 & $\begin{array}{l}\text { Pegal } \\
\text { linu }\end{array}$ & $\begin{array}{l}\text { Melaleucae } \\
\text { Retrofracti fructus, Zingeberis } \\
\text { aromaticae rhizoma, } \\
\text { Languatis rhizoma, Curcumae } \\
\text { rhizoma, Baeckeae folium, } \\
\text { Kaempferia rhizoma, } \\
\text { Zingiberis rhizoma, Blumeae } \\
\text { folium, Phyllanthi herba, } \\
\text { Cyperi rhizoma, Menthae } \\
\text { arvensitis herba, Foeniculli } \\
\text { fructus, Alyxiae cortex, } \\
\text { Usnae thallus, Dioscoreae } \\
\text { tubera. }\end{array}$ \\
\hline 4 & $\begin{array}{c}\text { Pegal } \\
\text { linu }\end{array}$ & $\begin{array}{l}\text { Retrofracti fructus, Eucalypti } \\
\text { fructus, Zingiberis aromaticae } \\
\text { rhizoma, Zingiberis rhizoma, } \\
\text { Curcumae rhizoma, Foeniculi } \\
\text { fructus, Alyxiae cortex, } \\
\text { Languatis rhizoma, Smilaxis } \\
\text { rhizoma, Parkiae semen, } \\
\text { Orthosiphonis } \\
\text { Burmanni cortex, Coptici } \\
\text { fructus, Piperis nigri fructus, } \\
\text { Phyllanthi herba. }\end{array}$ \\
\hline 5 & Sendi & $\begin{array}{lr}\text { Zingiberis } & \text { rhizoma, } \\
\text { Curcumae } & \text { domesticae } \\
\text { rhizoma, } & \text { Curcumae } \\
\text { aeruginosae } & \text { rhizoma, } \\
\text { Languatis } & \text { rhizoma, } \\
\text { Myristicae semen, Saussureae }\end{array}$ \\
\hline
\end{tabular}

lappae radix, Retrrofracti fructus.

6 Obahama Nigella sativa, Phaleria macrocarpa, Sida rhombifolia, Andrographis paniculata.

7 Asira Syzgium polyanthum folium, Curcumae domestica rhizoma, Alpinia galanga rhizoma, Zingiberis officinale rhizoma, Nigella sativa semen, Piantaginis majoris folium, Zingiberis aromaticae rhizoma.

8 Encok Equiseti herba, Zingiberis rhizoma, Blumeae folium, Myristicae semen, Curcumae rhizoma, Orthosiphonis folium, Piperis nigri fructus.

Table 2. List of eight brands of marketed herbal afrodisiacs and the adulterated sildenafil citrate concentrations.

\begin{tabular}{ccc}
\hline No & $\begin{array}{c}\text { Sample } \\
\text { Name }\end{array}$ & $\begin{array}{c}\text { Dexamethasone } \\
\text { concentration } \\
(\%)\end{array}$ \\
\hline 1 & Pegal linu & 5 and 85 \\
2 & Wantong & 10 \\
3 & Pegal linu & 15 \\
4 & Pegal linu & 20 \\
5 & Sendi & 25 \\
6 & Obahama & 40 \\
7 & Asira & 45 \\
8 & Encok & 80 \\
\hline
\end{tabular}

\section{Conclusion}

These results indicated that infrared spectroscopy combined with PLS is an alternative technique for the determination of adulterated dexamethasone in joint-pain killer traditional herbal medicine. 


\section{References}

Brereton, R.G., 2000. Introduction to multivariate calibration in analyticalchemistry. Analyst 125, 2125-2154.

Cebi, N., Yilmaz, M.T., Sagdic, O., 2017. A rapid ATR-FTIR spectroscopic method for detection of sibutramine adulteration in tea and coffee based on hierarchical cluster and principal component analyses. Food Chem. 229, 517-526.

Chen, J., Zhou, Q., Sun, S., 2016. Adulteration screening of botanical materials by a sensitive and model-free approach using infrared spectroscopic imaging and two-dimensional correlation infrared spectroscopy. J. Mol. Struct., Special Issue: Novel Developments and Applications of Two-Dimensional Correlation Spectroscopy 1124, 262-267.

Cho, S.-H., Park, H.J., Lee, J.H., Kim, H.J., Cho, S., Yoon, C.-Y., Kim, W.S., 2014. Monitoring of 35 illegally added steroid compounds in foods and dietary supplements. Food Addit. Contam. Part A 31, 1470-1475.

Curtis, J.R., Westfall, A.O., Allison, J., Bijlsma, J.W., Freeman, A., George, V., Kovac, S.H., Spettell, C.M., Saag, K.G., 2006. Population-based assessment of adverse events associated with long-term glucocorticoid use. Arthritis Care Res. 55, 420-426.
Faber, N.M., Rajk, R., 2007. How to avoid over-fitting in multivariate calibration: The Conventional Validation Approach and an Alternative. Anal. Chim. Acta 595, 98-106.

Hoes, J.N., Jacobs, J.W.G., Verstappen, S.M.M., Bijlsma, J.W.J., Van der Heijden, G., 2009. Adverse events of low-to medium-dose oral glucocorticoids in inflammatory diseases: a meta-analysis. Ann. Rheum. Dis. 68, 1833-1838.

Jin, P., Liang, X., Wu, X., He, X., Kuang, Y., Hu, X., 2018. Screening and quantification of 18 glucocorticoid adulterants from herbal pharmaceuticals and health foods by HPLC and confirmed by LC-Q-TOF-MS/MS. Food Addit. Contam. Part A 35, 10-19.

Moros, J., Garrigues, S., Guardia, M. de la, 2010. Vibrational spectroscopy provides a green tool for multicomponent analysis. TrAC Trends Anal. Chem. 29, 578-591.

Mukherjee, P.K., Houghton, P.J., 2009. Evaluation of herbal medicinal products: perspectives on quality, safety, and efficacy. Pharmaceutical Press, London; Chicago.

Poetker, D.M., Reh, D.D., 2010. A comprehensive review of the adverse effects of systemic corticosteroids. Otolaryngol. Clin. North Am. 43, 753-768. 
Rohman, A., 2013. Application of fourier transform infrared spectroscopy for quality control of pharmaceutical products. Indones. J. Pharm. 23, 1-8.

Rohman, A., . S., . D., Ramadhani, D., Nugroho, A., 2015. Analysis of Curcumin in Curcuma longa and Curcuma xanthorriza Using FTIR Spectroscopy and Chemometrics. Res. J. Med. Plant 9, 179-186.

Rohman, A., Che Man, Y.B., 2012. Quantification and Classification of Corn and Sunflower Oils as Adulterants in Olive Oil Using Chemometrics and FTIR Spectra. Sci. World J. 2012.

Rohman, A., Man, Y.B.C., 2010. Fourier transform infrared (FTIR) spectroscopy for analysis of extra virgin olive oil adulterated with palm oil. Food Res. Int. 43, 886892.

Rooney, J.S., McDowell, A., Strachan, C.J., Gordon, K.C., 2015. Evaluation of vibrational spectroscopic methods to identify and quantify multiple adulterants in herbal medicines. Talanta 138, 77-85.

Sanzini, E., Badea, M., Santos, A.D., Restani, P., Sievers, H., 2011. Quality control of plant food supplements. Food Funct. 2, 740746.

Vazquez, P.P., Galera, M.M., Frenich, A.G., Vidal, J.L.M., 2000. Comparison of Calibration
Methods with and without Feature Selection for the Analysis of HPLC Data. Anal. Sci. 16, 49-55.

W. J. Bijlsma, J., Buttgereit, F., 2016. Adverse events of glucocorticoids during treatment of rheumatoid arthritis: lessons from cohort and registry studies: Table 1. Rheumatology 55, ii3-ii5.

Zhang, C.Y., Chang, D.L., Chen, S.L., $2011 . \quad$ Simultaneous Determination of Five Nonsteroidal Anti-Inflammatory Drugs and Two Glucocorticoids in Adulterated Traditional Herbal Medicines for the Treatment of Rheumatism. Anal. Lett. 44, 1769-1782.

Zhou, S., Guo, C., Shi, F., Jiang, W., Wang, L., 2016. Application of an ultrahigh-performance liquid chromatography coupled to quadrupole-orbitrap highresolution mass spectrometry for the rapid screening, identification and quantification of illegal adulterated glucocorticoids in herbal medicines. J. Chromatogr. B 1038, 34-42. 